\title{
Developing Interactive E-book as Material Technology Coursebook by Flipbook Maker Software
}

\author{
Sulistianingsih AS* Annisa Carina \\ Lecturer of STT Stikma Internasional Malang, Indonesia
}

\begin{abstract}
The research is financed by DP2M DIKTI of Ministry of Research, Technology and Higher Education.
\end{abstract}
\section{Abstract}

Material technology course was one of the compulsory courses for Bachelor of Architecture Program in STT Stikma Internasional Malang. This course was offered in semester two (even semester) in the new academic year for 3 credits. This course aimed to make the students able to explain type, characteristic, and technical specification of some basic materials for construction, and its application in construction and some finishing material for construction. The insufficient laboratory facilities and infrastructure made the teaching material which were supposed to be done in laboratory must be done theoretically in classroom. The limited collection of books in the library also caused students difficulty in finding appropriate learning resources according to the course material. Therefore, this study aimed to produce interactive digital book products (e-books) on Material Technology courses which were appropriate and attractive to students, especially for Bachelor of Architecture in STT Stikma Internasional Malang. This research was a research and development model which main purpose was to produce products in the form of interactive digital books, especially for Material Technology courses. The development model used was the 4D model which consisted of 4 main steps: define, design, develop, and disseminate. Data collection techniques were carried out through observation, literature review and questionnaires. The questionnaire was used to carry out validation tests by material and media experts, as well as user development tests. The results of the material expert validation showed that this interactive e-book was very appropriate with an average percentage of $88.3 \%$. The validation results of the media experts indicated that this interactive e-book was very appropriate with an average percentage of $89.6 \%$. The results of the assessment involving 3 students as users also showed that this interactive e-book was very appropriate with a percentage of $88.8 \%$.

Keywords: Development; interactive e-book; material technology, Flipbook Maker

DOI: $10.7176 / \mathrm{JEP} / 10-24-03$

Publication date: August 31st 2019

\section{Introduction}

Technological advancements which are happening right now have changed our perspective or paradigm, especially in the world of education. One of the examples is related to the use of printed textbooks which have many limitations and disadvantages. The printed book which have been collected for years will reduce the quality of the book itself, making it difficult for readers to read and understand the contents of the book.

Making and using digital book (e-book) is one of the proper solutions for the problem. E-book is basically electronic version of digital book, which is the result of collaborative content between module and digital devices, which make it possible to form files with certain format which make them more efficient than the printed book. Whereas, interactive e-book can be categorized as a type of integrated media because they can collaborate on the existence of material texts, with various media such as images, video tutorials, audio, and simulation-based multimedia in it (Mawarni \& Muhtadi, 2017).

The use of interactive e-book can increase motivation, enthusiasm and provide psychological influence; thus, enabling students to study independently. Another advantage of e-book is that it can ease the readers and writers to collect and distribute their books, because the writers no longer need to come to publishers to publish their books (Hameed, Cheah, \& Rafie: 2010).

Material technology course is one of the compulsory courses for Bachelor of Architecture Program in STT Stikma Internasional Malang. This course aims to make students understand the basic knowledge about material technology and have the ability to plan the construction of wood, steel and concrete for buildings as well as to design the roof construction. Some problems found the by researchers were; 1) the insufficient laboratory facilities and infrastructure made the teaching material which were supposed to be done in laboratory must be done theoretically in classroom; 2) the limited collection of books in the library which made the students were difficult finding suitable learning resources for the course; and 3), the low reading motivation of the students which resulted in lack of understanding the course material.

The main objective of this research was to produce a textbook in the form of interactive e-books which could help the process of delivering lecture material on Material Technology to students, so that it would be more optimal, easily understood, and did not made them bored in their effort to understand the material. In addition, with this ebook, it was expected that students would not only be motivated during the lecture but also study independently outside the lecture hours, and able to do experiment related to the material presented. 
The research conducted by Yogiyatno \& Sofyan (2014) found that the use of interactive multimedia is more effective in improving student learning outcomes for basic competencies of operating database software. Siagian, et al. (2014) also found that most students gave positive responses to the interactive multimedia learning design and it able to increase their motivation and learning outcomes. Therefore, the use of interactive e-book was expected to have a positive effect on students especially in improving learning outcomes.

The development of e-books is inseparable from the application of the concept of module development and learning multimedia, which forms a digital book as an integrated module that contains interactively collaborated multimedia content. Thus, it can be stated that an interactive e-book is a comprehensive handout, which is a lecture module that is able to provide and present the material as a whole including one material from beginning to end in a creative and innovative way.

\section{Method}

\subsection{Research Design}

This research used the design of Research and Development (R\&D). R\&D is a research method used to produce a product. Sugiyono (2014) stated that research and development (R\&D) method is a research method used to produce certain products and test the effectiveness of the products. The development model used in this study was the Four-D model developed by Thiagarajan (1974). According to Thiagarajan (1974: 5), this model is called the 4D model because this design consists of 4 stages: define, design, develop, and disseminate as shown in the following diagram. In its development, researchers used Flipbook Maker software to create interactive e-book.

\subsection{Research Flow}

The development of interactive e-book in this research adapted the 4D model which was developed by Thiagarajan (1974). The following is the flow of interactive e-book development carried out in the research:

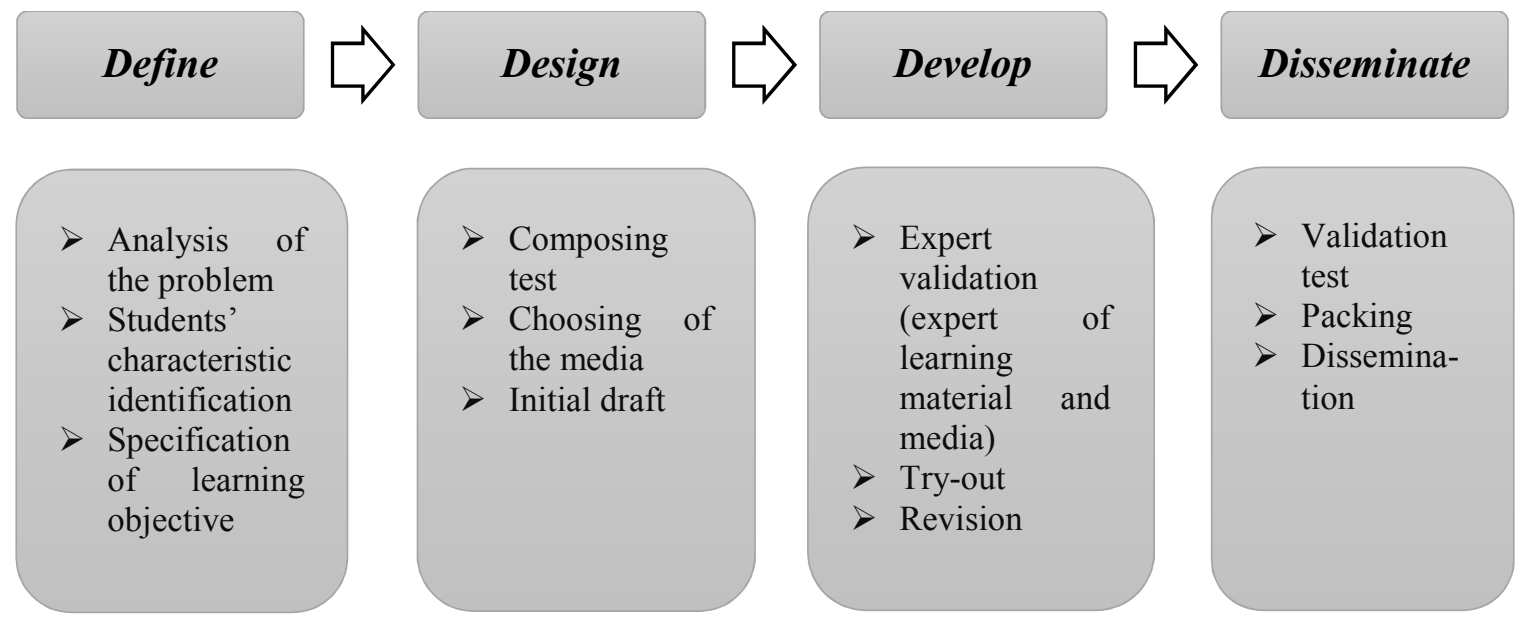

Figure 1. Stages of research and development (adaptation from 4D model, Thiagarajan)

Based on the diagram above, the stages of this research can be explained as follows:

1. Define

This stage aimed to determine and define student needs for learning media especially for Material Technology course and collect various information related to the product to be developed. This stage included 3 main steps namely, problem analysis, identification of student characteristics, and analysis of learning objectives specifications.

2. Design

After analyzing the problem and collecting various information at the defining stage, the next step is the designing stage. This stage aimed to design learning tools starting from the learning objectives. The design of the learning device itself was done through several steps, namely: 1) preparing test standards; 2) selecting media which was suitable with the material characteristics and learning objectives; 3 ) making the initial design according to the chosen format.

\section{Develop}

This stage aimed to produce development product which was carried out through two steps, namely 1) expert assessment (material expert and media expert) and followed by revision; and 2) development test, which was conducted by involving 3 students as sample. This step aimed to produce the final product in the form of ebook learning media after going through revisions based on experts' notes and try-out results data. 


\section{Disseminate}

After this interactive e-book had been developed, the final step was dissemination. The purpose of this stage was to disseminate the e-book learning media which had been produced. In this research, product dissemination was carried out to students of Bachelor Program of Architecture in STT International Stikma Malang.

\subsection{Data Collection Technique}

Data collection techniques used in this study were observation, literature review and questionnaire. Observation was carried out in the preliminary study to identify the problems faced by students, especially in Material Technology course. Furthermore, library research was used at the design and development stages of e-book product. Finally, the questionnaire was conducted through a validation sheet by experts and also students. This step was carried out to determine the assessment of experts and also the response of students to the e-book had been developed, so that it could be revised or improved.

\subsection{Data Analysis Technique}

Data obtained from the results of the questionnaire was then analyzed. The data was analyzed by using a Likert scale which was used to measure the attitudes, opinions, and perceptions of a person or group of people about social phenomena (Sugiyono, 2014). The answer to each item of instruments which used a Likert scale ranged from very appropriate to inappropriate.

Table 1. Division of score to respondents' answer

\begin{tabular}{|l|c|}
\hline \multicolumn{1}{|c|}{ Respondents' answer } & Score \\
\hline Very appropriate & 5 \\
\hline Appropriate & 4 \\
\hline Enough appropriate & 3 \\
\hline Less appropriate & 2 \\
\hline Inappropriate & 1 \\
\hline
\end{tabular}

(Riduwan, 2010)

The data obtained was then went through data tabulation and made into percentage by the following formula:

$$
P(\%)=\frac{\text { interval score }}{\text { maximum interval score }} \times 100 \%
$$

Based on the formula above, the class interval of validity and development test for the e-book developed can be illustrated in a percentage in Table 2 .

Table 2. Criteria of product appropriateness

\begin{tabular}{|l|l|}
\hline \multicolumn{1}{|c|}{ Interval of assessment } & \multicolumn{1}{c|}{ Criteria } \\
\hline $81 \%<$ percentage $\leq 100 \%$ & Very appropriate \\
\hline $61 \%<$ percentage $\leq 80 \%$ & Appropriate \\
\hline $41 \%<$ percentage $\leq 60 \%$ & Enough appropriate \\
\hline $21 \%<$ percentage $\leq 40 \%$ & Less appropriate \\
\hline $0 \% \leq$ percentage $\leq 20 \%$ & Inappropriate \\
\hline
\end{tabular}

(Riduwan, 2010)

\section{Result}

3.1 Result of Development

The result of this development research was an interactive e-book of Material Technology course for Architecture students of STT Stikma International Malang. The following is an example of how each chapter in the e-book: 


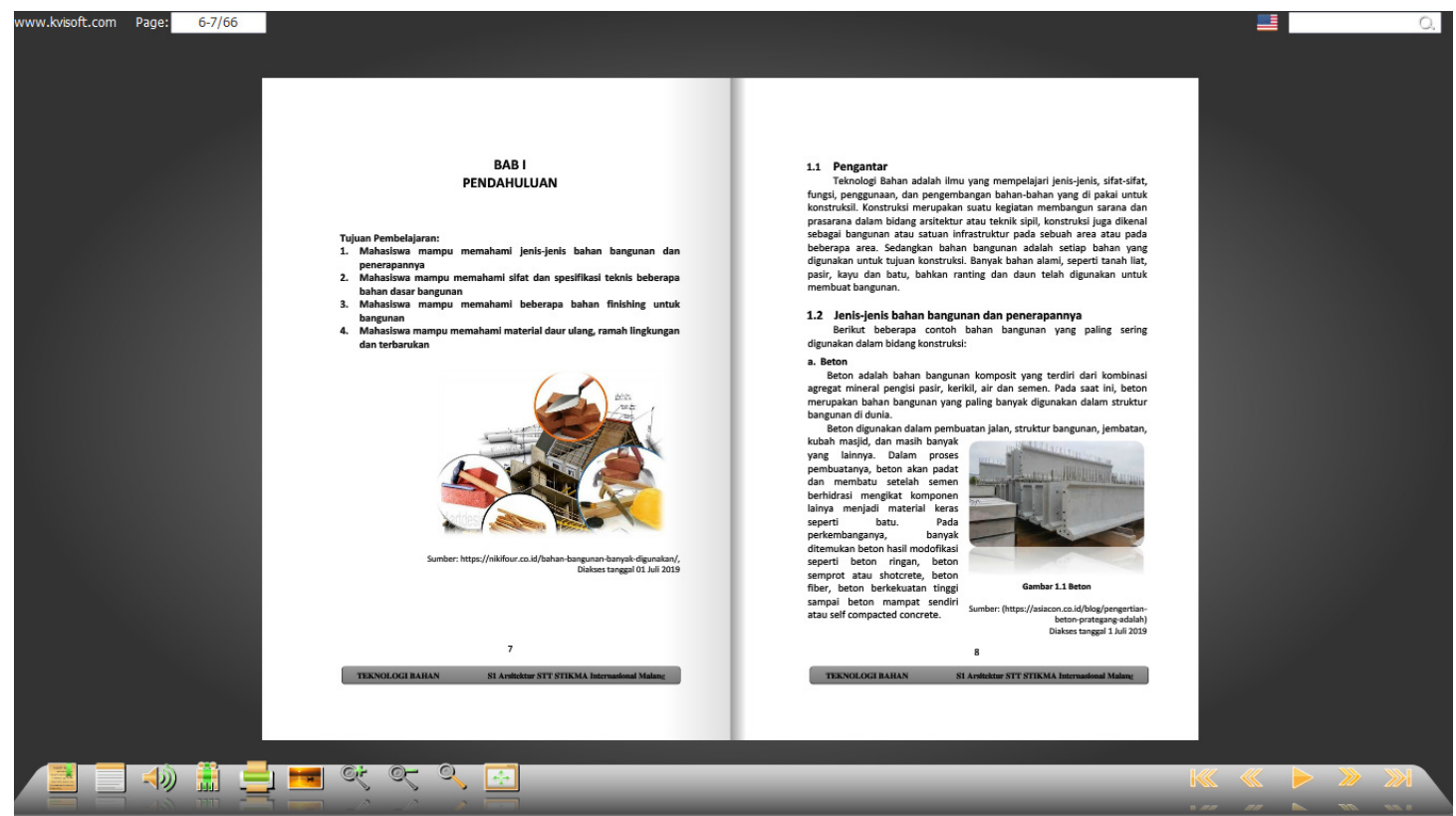

Figure 2. The example of each chapter's display in e-book

The picture above shows the display of the e-book in each chapter. Each chapter in the book began with the title of the chapter and also the learning objectives before going further into the contents of the material. The ebook was very easy to use, because the features in the book were complete, such as bookmarks, music, zoom in, zoom out, text search and other features to facilitate the user in running the product. In addition to an attractive flipbook display, this e-book was also equipped with additional video tutorials. This video tutorial was added to make it easier for students to understand the material being discussed as shown in the following figure.

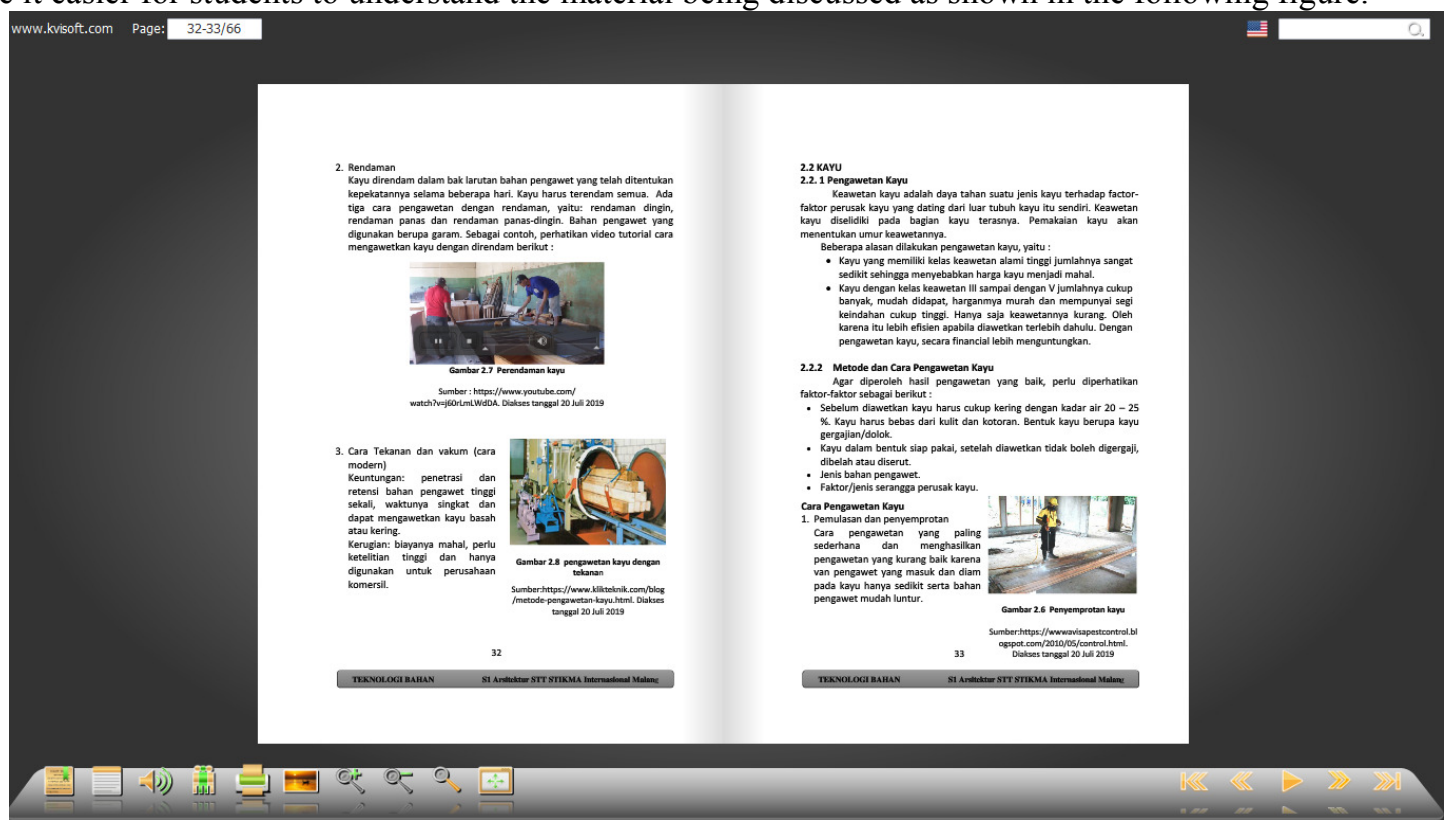

Figure 3. E-book display which was equipped with video

\subsection{Discussion}

This section discussed the results of validation conducted by experts (material and media experts) and also the results of development tests conducted to 3 students. The following are the results of the validation and try-out. 
Table 3. Validation of material expert

\begin{tabular}{|c|l|c|c|c|c|}
\hline No. & \multicolumn{1}{|c|}{ Indicator } & Item & Score & Average & $\%$ \\
\hline 1. & The appropriateness of the & 1 & 5 & & \\
& material with course outline and & 2 & 5 & 4.75 & 95 \\
& lesson plan & 3 & 4 & & \\
\hline 2. & Relevance of the material & 5 & 5 & & \\
& & 6 & 4 & 4.25 & \\
& & 7 & 4 & & \\
\hline 3. & Overall material & 9 & 5 & \\
& & 11 & 4 & & \\
& & 12 & 4 & & \\
& & 13 & 4 & & \\
& & 14 & 4 & & \\
& & 15 & 4 & & \\
\hline
\end{tabular}

Score from the expert's assessment for material aspects of interactive e-book are as follows: 1) suitability of the material with course outline and lesson plan was $95 \%$; 2) material relevance was $85 \%$; and 3 ) the overall material was $85 \%$. Thus, from the 3 indicators of material assessment, an average score of $88.3 \%$ was obtained or included in the very appropriate category.

Table 4. Validation of media expert

\begin{tabular}{|c|c|c|c|c|c|}
\hline No. & Indicator & Item & Score & Average & $\%$ \\
\hline 1. & Display of e-book & $\begin{array}{l}1 \\
2 \\
3\end{array}$ & $\begin{array}{l}5 \\
5 \\
4\end{array}$ & 4.66 & 93 \\
\hline 2. & $\begin{array}{l}\text { The use of image, audio, and video } \\
\text { in e-book }\end{array}$ & $\begin{array}{c}4 \\
5 \\
6 \\
7 \\
8 \\
9 \\
10\end{array}$ & $\begin{array}{l}4 \\
4 \\
4 \\
5 \\
5 \\
4 \\
5\end{array}$ & 4.43 & 88 \\
\hline 3. & Navigation system of e-book & $\begin{array}{l}11 \\
12 \\
13 \\
14 \\
15\end{array}$ & $\begin{array}{l}5 \\
4 \\
4 \\
5 \\
4\end{array}$ & 4.40 & 88 \\
\hline & \multicolumn{4}{|l|}{ Average } & 89.6 \\
\hline
\end{tabular}

Score from the expert's assessment for media aspects of interactive e-book are: 1) aspects of e-book display was $93 \%$; 2) the use of images, audio and video in e-books was $88 \%$; and 3) e-book navigation system was $88 \%$. Thus, from the 3 indicators of media display assessment, an average score of $89.6 \%$ was obtained or included in the very appropriate category. 
Table 5. Try-out of the product by 3 students

\begin{tabular}{|c|c|c|c|c|c|c|c|}
\hline \multirow{2}{*}{ No. } & \multirow{2}{*}{ Indicator } & \multirow{2}{*}{ Item } & \multicolumn{3}{|c|}{ Score } & \multirow{2}{*}{ Average } & \multirow{2}{*}{$\%$} \\
\hline & & & Stud. I & Stud. II & Stud. III & & \\
\hline \multirow[t]{3}{*}{1.} & Content & 1 & 4 & 5 & 4 & \multirow{3}{*}{4.44} & \multirow{3}{*}{88} \\
\hline & & 2 & 5 & 5 & 5 & & \\
\hline & & 3 & 4 & 4 & 4 & & \\
\hline \multirow[t]{4}{*}{2.} & Ease of the & 4 & 4 & 4 & 4 & \multirow{4}{*}{4.42} & \multirow{4}{*}{88} \\
\hline & product's & 5 & 5 & 5 & 4 & & \\
\hline & operation & 6 & 4 & 4 & 5 & & \\
\hline & & 7 & 5 & 4 & 5 & & \\
\hline \multirow[t]{3}{*}{3.} & Navigation menu & 8 & 5 & 5 & 5 & \multirow{3}{*}{4.55} & \multirow{3}{*}{91} \\
\hline & & 9 & 4 & 5 & 4 & & \\
\hline & & 10 & 4 & 4 & 5 & & \\
\hline \multirow[t]{3}{*}{4} & E-book display & 11 & 5 & 5 & 4 & \multirow{3}{*}{4.55} & \multirow{3}{*}{91} \\
\hline & & 12 & 4 & 5 & 4 & & \\
\hline & & 13 & 5 & 4 & 5 & & \\
\hline \multirow[t]{3}{*}{5} & Language use & 14 & 4 & 4 & 5 & \multirow[t]{3}{*}{4.33} & \multirow[t]{2}{*}{86} \\
\hline & & 15 & 5 & 4 & 4 & & \\
\hline & \multicolumn{5}{|l|}{ Average } & & 88.8 \\
\hline
\end{tabular}

Assessment scores for the display aspect of interactive e-book from the media expert was obtained as follows: 1) the content of the material was $88 \%$; 2) ease of operation was $88 \%$; 3) navigation menu was $91 \%$; 4) e-book display design was $91 \%$; and 5) language use was $86 \%$. Thus, from the 3 indicators of media display assessment, an average score of $88.8 \%$ was obtained or included in the very appropriate category.

Based on the validation carried out by material experts, media experts and try-out on 3 students, there has been several revisions made to the e-book. The product revisions were among others: 1) the addition of the contents of the material in chapter 2 about wood and its application in the architectural field; 2) changes in the use of font types and colors in the script; 3 ) addition of pictures of various materials and examples of their use to clarify the delivery of material.

In general, this e-book had an interactive and attractive appearance, and was easy to use. The presentation of the book could also help students understand the material. This interactive e-book had a good level of clarity between learning objectives, exposure to material, and assignments or worksheets, so that the content was easily understood by students. Thus, this interactive e-book had several advantages, namely: 1) easy to use; 2) relevant learning material; and 3) interactive multimedia to increase student motivation. This result was in accordance with the results of research by Setuju and Priyanto (2015) who stated that through the use of appropriate media, all objects can be presented to students.

The use of media allowed the interaction between students and the environment, created uniform observations and could deliver the basic concept which was correct, concrete, and realistic. According to Wahyuningtyas \& Ratnawati (2016), the use of interactive multimedia makes the learning process more interesting. It could be seen from the activeness of students in asking questions and students' abilities in responding to the delivery of material given. Thus, it could be stated that the use of interactive multimedia was able to generate new willingness and interest, increase motivation and stimulate students to learn, and get a comprehensive experience.

\section{Conclusion}

The result of this research and development was an interactive e-book of Material Technology course for Bachelor of Architecture students of STT Stikma Internasional Malang, which was carried out with the adaptation of the 4D development model from Thiagarajan (1974). The results of the material expert validation showed that this interactive e-book was very appropriate with an average percentage rating of $88.3 \%$ which included 3 aspects of assessment namely the suitability of the material with the learning tools, the relevance of the material and the overall content of the material. The results of the validation of media expert indicated that this interactive e-book was very appropriate with an average percentage rating of $89.6 \%$ which included 3 aspects namely e-book display, use of images, audio and video in e-books and navigation systems. Moreover, the results of the try-out involving 3 students as users showed that this interactive e-book was very appropriate, with an assessment rate of $88.8 \%$ covering 5 aspects namely material content, ease of operation, navigation menus, e-book display design and language use in e-book.

\section{Acknowledgement}

The researchers would like to deliver the gratitude to DP2M DIKTI of Ministry of Research, Technology and Higher Education for the grant through the scheme of Penelitian Dosen Pemula (PDP) 2019, with the contract letter Number 063.1/A-STIKMA/KP/I/III/2019. 


\section{References}

Hameed, N., Cheah, Y. N., \& Rafie, M. (2010), "An e-book personalization architecture with digital rights and encryption procedures", Information Technology ITSim 2010 International Symposium in.

Haris, D. (2011). Panduan Lengkap E-book. Yogyakarta : Cakrawala Sketsa.

Mawarni, S \& Muhtadi, A. (2107), "Pengembangan Digital Book Interaktif Mata Kuliah Pengembangan Multimedia Pembelajaran Interaktif untuk Mahasiswa Teknologi Pendidikan”, Jurnal Inovasi Teknologi Pendidikan, 4(1), 84-96.

Riduwan. (2010). Skala Pengukuran Variabel-variabel Penelitian. Bandung: Alfabeta.

Siagian, S., Mursid \& Wau, Y. (2014), "Development of Interactive Multimedia Learning in Learning Instructional Design", Journal of Education and Practice, 5(32), 44-50.

Setuju \& Priyanto, S. (2015), "Penerapan Media Pembelajaran Multimedia Dalam Upaya Meningkatkan Efektifitas Pembelajaran Pada Mata Pelajaran Gambar Teknik Mesin I Kelas X Pemesinan di SMK Muhammadiyah Prambanan", Jurnal Taman Vokasi, 1(1), 84-94.

Sugiyono. 2014. Penelitian Pendidikan Pendekatan Kuantitatif, Kualitatif dan R\&D. Bandung: Alfabeta.

Thiagarajan, S., Semmel, D. S \& Semmel, M. I. (1974), "Instructional Development for Training Teachers of Exceptional Children: A Sourcebook", Washington D. C., National Center for Improvement of Educational System.

Yogiyatno, W. \& Sofyan, H. (2014), "Pengembangan Multimedia Interaktif Kompetensi Dasar Mengoperasikan Software Basis Data Untuk SMK Negeri 1 Seyegan”, Jurnal Pendidikan Vokasi, 4(1), 111-124.

Wahyuningtyas, N. \& Ratnawati, N. (2016), "Interactive Multimedia as Autonomous Learning Resource in the South Slope of Kelud Mt. In Blitar Regency” Journal of Education and Practice, 7(29), 168-171.

Sulistianingsih AS. was born in Ujung Pandang, January $08^{\text {th }} 1988$; obtained her bachelor degree from Universitas Negeri Makassar; and obtained her master degree from Universitas Negeri Malang, Indonesia. Her main interests are civil engineering and vocational education.

Annisa Carina was born in Lamongan, November $20^{\text {th }} 1990$; obtained her bachelor degree from Universitas Negeri Malang; obtained her master degree also from Universitas Negeri Malang, Indonesia. Her main interests are civil engineering and vocational education. 